\title{
PENGGUNAAN JILBAB BAGI POLWAN PERSPEKTIF PEMBERITAAN HARIAN REPUBLIKA EDISI JUNI-DESEMBER 2013
}

\author{
Riyadhotul Munawaroh, Rustini Wulandari, Hasyim Hasanah \\ Universitas Islam Negeri (UIN) Walisongo Semarang \\ e-mail: riyadhotu191@gmail.com,rustini_wulandari@yahoo.co.id, \\ hasyimhasanah_82@yahoo.co.id
}

\begin{abstract}
Abstrak
Fokus penelitian pada pemberitaan penggunaan jilbab bagi polisi wanita dalam Surat Kabar Harian Republika, dengan jenis berita straight news. Penelitian bertujuan untuk mengetahui, mendeskripsikan, dan menganilisis konstruksi wacana Surat Kabar Harian Republika mengenai pemberitaan penggunaan jilbab bagi polisi wanita. Penelitian ini menggunakan jenis penelitian kualitatif dengan metode analisis wacana Teun A van Dijk. Teknik pengumpulan data penelitian menggunakan dokumentasi teks berita dalam Surat Kabar Harian Republika edisi Juni-Desember 2013. Penelitian menghasilkan simpulan mengenai konstruksi wacana dalam pemberitaan penggunaan jilbab polwan yaitu, pertama, Republika tidak setuju saat Kapolri belum mengizinkan penggunaan jilbab polwan, alasannya bertolak belakang dengan Undang-Undang Dasar 1945 dan perintah agama untuk menutup aurat. Kedua, Republika mendukung sikap Kapolri saat memberi izin secara lisan kepada polwan untuk berjilbab dan menghendaki segera ada peraturan yang memperkuat kebijakan. Ketiga, Republika tidak setuju adanya peraturan penundaan penggunaan jilbab polwan, menganggap ganjil kebijakan tersebut, dan memandang terdapat kelompok antijilbab di tubuh kepolisian. Republika terlihat mengharapkan polwan dapat bebas berjilbab saat bertugas tanpa perlu mengkhawatirkan adanya teguran. Hal tersebut terlihat dari pemilihan narasumber berita yang kebanyakan memiliki harapan sama dengan Republika. Kutipan wawancara narasumber yang menginginkan polwan berjilbab diberi porsi lebih banyak dan ada yang diletakkan pada awal serta akhir berita. Penulis memberikan saran bagi wartawan untuk lebih berimbang dalam meyajikan berita, baik dari pemilihan narasumber, peletakan kutipan wawancara, maupun pengambilan sudut pandang, agar tidak terlihat berpihak dan menjadi berita provokasi. Penulis memberi rekomendasi kepada Polri untuk memasukkan jilbab dalam
\end{abstract}


standard operating procedure seragam dinas kepolisian. Hal tersebut dimaksudkan agar polisi wanita tidak terlalu lama menunggu Parlemen menyetujui anggaran penyediaan jilbab, karena menutup aurat menjadi hak yang dilindungi konstitusi. Bagi DPR, seharusnya membuat kebijakan atau undangundang yang menjamin penggunaan jilbab dan berlaku di tingkat nasional.

Kata Kunci: penggunaan jilbab; polwan; Harian Repubika

\section{A. Pendahuluan}

Indonesia dikenal sebagai negara dengan jumlah Muslim terbesar di dunia. Fitriyan Zamzani dalam artikelnya di Surat Kabar Republika, menyatakan jumlah Muslim di Indonesia sebanyak 86 persen, lebih banyak dari negara lain. ${ }^{1}$ Indonesia menjamin hak warga negaranya untuk beragama. Meliputi hak memilih agama dan beribadah menurut agama serta kepercayaannya. Jaminan hak tersebut tertuang dalam Undang-Undang Dasar (UUD) 1945 pasal 29, serta Pancasila sila pertama Ketuhan Yang Maha Esa Terdapat permasalahan dalam penerapannya, yaitu jaminan tersebut belum sepenuhnya dirasakan sebagian wanita Muslim Indonesia, diantaranya mereka yang ingin mengenakan jilbab sebagai perintah agama. Contohnya pada karyawan bank, pegawai pabrik, perusahaan, bahkan institusi kepolisian pun mengalami kendala dalam penggunaan jilbab bagi polisi wanita (polwan) saat bekerja. Permasalahan tersebut menjadi topik hangat yang diperdebatkan berbagai media massa pada Juni 2013. Permasalahan itu muncul ketika Majelis Ulama Indonesia mendapat pengaduan dari seorang polwan yang tidak diperbolehkan mengenakan jilbab saat bertugas. Terdapat anggapan, bahwa jilbab mengganggu kinerja polwan saat bekerja di lapangan, selain itu dalam Surat Keputusan (SK) Kepala Kepolisian Republik Indonesia (Kapolri) Nomor Pol.: Skep/ 702/IX/2005. Jilbab tidak termasuk dalam Standard Operating Procedure (SOP) seragam yang harus dipakai, dan terdapat sanksi bila melanggar peraturan tersebut. ${ }^{2}$ Penerapan peraturan Surat Keputusan Kapolri mengenai seragam dinas polisi tidak berlaku di Nangroe Aceh Darussalam. Sejak tahun 2004 institusi

${ }^{1}$ Fitriyan Zamzani, “Momen Polri Merengkuh Kemanusiaan”. Republika. No. 155 Tahun 21. Edisi 14 Juni 2013.

${ }^{2}$ Rosita Budi Suryaningsih, "Polwan Minta Izin Berjilbab". Republika. No. 147 Tahun 21. Edisi 5 Juni 2013. 
kepolisian Aceh memperbolehkan polwan Muslim mengenakan jilbab. Alasannya, memakai jilbab sudah menjadi peraturan daerah yang harus dipatuhi. Negara Kanada, Jerman, dan Denmark yang mayoritas non Muslim juga sudah memperbolehkan seragam berjilbab bagi polwan. ${ }^{3}$

Bagi sebagian polwan Muslim, menutup aurat merupakan hal yang ingin dilakukan, karena itu adalah perintah agama. Pemakaian jilbab diharapkan mengurangi pelecehan seksual yang terjadi pada polwan dari sesama anggota polisi dan pihak lain karena berpakaian cenderung ketat. Salah satu contoh kasus tersebut terjadi pada Brigadir Polisi Satu (Briptu) Rani Indah Yuni Nugraeni. Briptu Rani mendapat pelecehan saat pengukuran seragam dinas yang dilakukan atasannya, Kepala Kepolisian Resor (Kapolres) Mojokerto, Ajun Komisaris Besar Polisi (AKBP) Eko Puji Nugroho. AKBP Eko mengukur baju Briptu Rani langsung ke badannya. Tindakan tersebut merupakan penyalahgunaan kekuasaan dengan melecehkan anak buah yang tidak sepatutnya dilakukan pimpinan (Pitakasari, diakses 18 November 2013). ${ }^{4}$

Perizinan penggunaan jilbab bagi polwan mendapat titik terang. Kapolri Jenderal Sutarman memberikan izin secara lisan pada polwan untuk menggunakan jilbab mulai 20 November 2013, tanpa perlu menunggu keluarnya peraturan Kapolri (perkap) darinya. Syaratnya, membeli sendiri jilbab yang sama dengan model dan warna seragam polwan Aceh, karena Polri belum menganggarkan dana penyediaan, akan tetapi pelaksanaannya masih mengalami kendala (Prambadi, edisi 20 November 2013). ${ }^{5}$ Pada 28 November 2013 terdapat kebijakan penundaan jilbab yang termuat dalam telegram rahasia, ditandatangani oleh Wakil Kepala Polri Komisaris Jenderal Oegroseno. Telegram rahasia tersebut berisi enam imbauan kepada polwan untuk menunda penggunaan jilbab ketika berdinas. Berlaku hingga parlemen menyepakati anggaran penyediaan jilbab dan terbitnya aturan mengenai seragam tersebut. Perubahan kebijakan itu dikarenakan banyaknya polwan yang mengenakan jilbab warna-warni saat bertugas (Prambadi, edisi 30 November 2013). ${ }^{6}$ Kebijakan tersebut dinilai

"Gilang Akbar Prambadi dan Alicia Saqina, "Jilbab tak Ganggu Polwan". Republika. No. 149 Tahun 21. Edisi 8 Juni 2013.

${ }^{4}$ Ibid.

${ }^{5}$ Ibid.

${ }^{6}$ Ibid. 
berlawanan dengan syariat Islam. Islam menganjurkan wanita Muslim melaksanakan hal yang Allah wajibkan, berupa ibadah dan amal saleh seperti perintah menutup aurat dengan jilbab agar terjaga kehormatannya. ${ }^{7}$ al-Qur'an juga telah menjelaskan perintah Allah tentang kewajiban wanita menutup aurat serta menggunakan jilbab demi menjaganya saat berada di luar rumah dalam surat al-Ahzab ayat 59. Ayat tersebut berbicara mengenai fungsi pakaian sebagai pembeda antara seseorang dengan orang lain dalam sifat atau profesinya. Jilbab dalam al-Ahzab diartikan sebagai sejenis baju kurung yang lapang, dapat menutup kepala, muka, dan dada. ${ }^{8}$

Menurut al-Asymawi dari Tafsir al-Qurthubi (dalam Shihab), surat alAhzab ayat 59 berkaitan dengan kebiasaaan wanita-wanita Arab pada masa turunnya al-Qur'an, yakni kurang memperhatikan kesopanan berpakaian dan bertingkah laku. Ketika wanita mukmin atau merdeka itu hendak buang air di padang pasir, mereka mendapat gangguan dari laki-laki jahil karena membuka wajahnya dan diduga sebagai wanita tidak terhormat. Wanita merdeka mengadu perihal kejadian tersebut pada Nabi, lalu turunlah ayat tersebut sebagai pembeda antar mereka. ${ }^{9}$ Para ulama memiliki perbedaan pendapat mengenai penerapan ayat tersebut dalam kehidupan umat Muslim setelah zaman Nabi. Sekarang ini tempat untuk membuang air telah tertutup, tetapi konteks penerapan pembeda tersebut tidak harus saat buang air saja. Banyak wanita Muslim yang diganggu dan mendapat tindak pelecehan seksual dari lelaki jahil karena berpakaian kurang sopan serta tidak pada tempatnya. Pemakaian jilbab sesuai syariat memiliki banyak manfaat daripada kejelekannya, sehingga baik digunakan untuk polwan Muslim yang sering mendapat tindak pelecehan karena berpakaian cenderung ketat. Melihat hal tersebut, seharusnya tidak ada permasalahan mengenai penggunaan jilbab, sebab berjilbab adalah hak bagi manusia. Jilbab disyariatkan untuk menyempurnakan pribadi wanita ketika keluar rumah, dengan manfaat sebagai pembeda, penjaga diri, dan penghormatan, meskipun konsep jilbab sendiri bukan milik Islam. Amin (dalam Shihab) menjelaskan jilbab atau hijab merupakan pakaian yang dikenal karena adat

\footnotetext{
${ }^{7}$ Kholid Mustafa, Manajemen Wanita Salehah, (Yogyakarta: Diva Press. 2009), h. 175 .

${ }^{8}$ Abdul Halim Abu Syuqqah, Kebebasan Wanita, (terj) As'ad Yasin, Jakarta: Gema Insani Press, 1997), h. 57.

${ }^{9}$ M. Quraish Shihab, Jilbab Pakaian Wanita Muslimah, (Jakarta: Lentera Hati, 2005), h. 143-144.
} 
kebiasaan, lahir akibat pergaulan masyarakat Mesir (Islam) dengan bangsabangsa lain, kemudian mereka anggap baik, meniru serta menilainya sebagai tuntunan agama. ${ }^{10}$

Jilbab telah dipakai kaum wanita di zaman Jahiliah, akan tetapi cara memakainya tidak seperti jilbab sekarang ini yang menutup seluruh kepala, leher, dan dada. Wanita Jahiliah hanya menutup kepala, sementara rambut dan leher mereka masih terlihat karena berbahan tipis serta terpengaruh kebiasaannya menonjolkan perhiasan. Dasar tujuan pemakaian jilbab juga karena adat kebiasaan, yang kemudian diteruskan wanita pada zaman selanjutnya. ${ }^{11}$ Model jilbab yang dipakai wanita Muslim sekarang bukan berarti meniru kebiasaan wanita Jahiliah. Islam mewajibkan para wanita menutup aurat, sebagai identitas Muslimah. Salah satu sifat wanita teladan, tunduk secara total kepada Allah dalam segala hal, artinya segala sikap dan tingkah lakunya sesuai dengan tuntunan Islam, tidak melakukan suatu amal kecuali berdasarkan petunjuk Islam dan tidak meniggalkan suatu amal kecuali berdasarkan ajaran Islam. ${ }^{12}$ Hal tersebutlah yang ingin dikerjakan sebagian polwan Muslim Indonesia, menutup aurat dengan menggunakan jilbab saat bardinas.

Tema penggunaan jilbab bagi polisi wanita telah menjadi headline di media massa, salah satunya pada Surat Kabar Harian Republika awal Juni 2013. Republika biasa disebut koran hijau karena pembacanya mewakili golongan Muslim Indonesia, sehingga permasalahan terkait keislaman seperti penggunaan jilbab lebih tepat sasaran. Republika menerapkan kaidah pemberitaan yang profesional tanpa meninggalkan misi keislaman dalam konteks jurnalisme..$^{13}$ Republika merupakan surat kabar berideologi Islam, wartawan media tersebut minimal memiliki pengetahuan mengenai masalah keislaman. Penulis memilih tema berita penggunaan jilbab karena menyangkut kepentingan berbagai kalangan masyarakat, khususnya pol-

${ }^{10}$ Ibid.

${ }^{11}$ Muchlis Muhammad Hanafi, dkk., Kedudukan dan Peran Perempuan (Tafsir alQur'an Tematik), Jakarta: Lajnah Pentashihan Mushaf al-Qur'an Badan Litbang dan Diklat Departemen Agama RI., 2009), h. 157.

${ }^{12}$ Abdul Mu'min Ibrahim, Mendidik Anak Perempuan. (terj) Abdul Hayyie alKattani dan Mujiburrahman Subadi, (Jakarta: Gema Insani Press, 2007), h. 173.

${ }^{13}$ Suf Kasman, Pers dan Pencitraan Umat Islam di Indonesia (Analisis Isi Pemberitaan Harian Kompas dan Republika). (Jakarta: Balai Litbang dan Diklat Kementrian Agama RI, 2010), h. 167-171. 
wan Muslim. Tidak hanya polwan yang merasa dibatasi haknya untuk berjilbab, sebagian wanita pekerja diharuskan melepas jilbab saat bekerja, akan tetapi masalah itu belum direspon oleh pihak yang menjamin kebebasan menjalankan syariat agama. Republika menyajikan banyak berita mengenai tema penggunaan jilbab bagi polisi wanita, pendapat narasumber dari berbagai kalangan juga dituangkan untuk megimbangi informasi. Terdapat lebih dari 30 berita yang dimuat Republika pada bulan JuniDesember 2013, di antaranya berjudul "Polwan Minta Izin Berjilbab", "Jilbab Polwan Ditunda", dan lainnya. Peran wartawan sebagai orang yang mengumpulkan, mengolah berita, serta harus menyajikan sesuai fakta dan bersifat netral diperlukan dalam permasalah ini. Berita muncul tidak dengan sendirinya, terdapat sebuah proses yang melibatkan kognisi seorang wartawan. Wartawan harus menggali berita sesuai kebenaran kejadian yang dihimpun dari narasumber terkait peristiwa tersebut. Proses penyeleksian juga harus dilakukan karena tidak semua informasi narasumber bersifat benar, baik, dan bermanfaat bagi pembaca, oleh karena itu wartawan diharuskan melakukan check and recheck terhadap berita yang didapat agar tidak menyebabkan fitnah. ${ }^{14}$ Berita dikatakan benar jika memuat laporan secara tepat tentang apa yang terjadi di lapangan. Jika terdapat liputan mengenai pertikaian warga, wartawan tidak diperbolehkan memihak salah satu pihak bertikai. Wartawan seharusnya memberi perspektif baru berkaitan dengan konflik yang terjadi, jika membela salah satu pihak, maka sudah tidak objektif lagi. Berita bukanlah kejadiannya sendiri, tetapi merupakan kejadian aktual yang dikelilingi banyak persoalan. Objektivitas murni tidaklah ada, kejadian merupakan fakta objektif, tetapi bagaimana kejadian itu dipilih, dipilah, diberi makna, diinterpretasi, dan bagaimana cara melaporkannya adalah suatu yang subjektif. Sudut pandang wartawan yang berbeda-beda dan media tempat wartawan bekerja bisa mempengaruhi tingkat subjektivitas. Media seringkali berperan dalam penyajian teks berita wartawan. Pembaca bisa mengamati hal tersebut dari penulisan berita yang terkesan memihak salah satu pihak, padahal tugas wartawan yaitu menyampaikan peristiwa sesuai fakta dengan tidak ada faktor keberpihakan di dalamnya. Penulis tertarik meneliti permasalahan yang telah dipaparkan di atas, bertema penggunaan jilbab bagi polisi wanita dan menganalisisnya

\footnotetext{
${ }^{14}$ Ahmad Y. Samantho, Jurnalistik Islami; Panduan Praktis bagi Para Aktivis Muslim. (Jakarta: Harakah, 2002), h. 68.
} 
menggunakan pendekatan analisis wacana. Melalui analisis wacana akan diketahui konstruksi pemberitaan tema tersebut, sehingga memperoleh suatu pengetahuan mengapa teks bisa memiliki makna beragam, dan selanjutnya mendeskripsikan, dan menganalisis konstruksi wacana pemberitaan penggunaan jilbab.

\section{B. Pembahasan}

Republika adalah koran komunitas Islam. Ciri khas tersebut menjadikan pasar Republika lebih segmentatif. Republika berusaha agar produknya tidak hanya ditujukan untuk mendukung partai politik atau orang saleh, tetapi untuk orang-orang yang belum mantap imannya dan segan dengan seruan moralistik. Kehadiran Republika bukan hanya menjadi saluran bagi aspirasi umat Islam, melainkan mendorong tumbuhnya pluralisme informasi di masyarakat. Republika memberikan informasi komprehensif bagi segmen pembaca dengan strategi pengembangan produk, yaitu berusaha menyajikan berita umum dan nuansa keislaman secara lengkap serta seimbang. Dari segi prospek dan potensi pembaca, pelanggan harian Republika telah menyebar ke seluruh tanah air. Sebagian besar pelanggan tersebut adalah umat Islam, dengan motivasi berlangganan untuk menyalurkan aspirasi keagamaan. ${ }^{15}$

Republika memiliki perbedaan dengan surat kabar lain, misalnya dalam pengemasan, pendalaman, dan penyajian. Republika cenderung menyajikan berita secara atraktif, jelas, dan tuntas, sehingga tidak memerlukan banyak energi untuk memahaminya. Bahasa dan gaya penuturan bersifat populer, renyah, dan tidak kaku, tanpa mengabaikan kaidah bahasa Indonesia. Pada bagian desain dan visualisasi, Republika menonjolkan unsur grafis yang informatif berupa gambar, foto, dan tabel, terdapat pula eksplorasi warna dalam penyajian berita. Ciri tersebut menjadi kekuatan Surat Kabar Republika untuk menarik pembaca. ${ }^{16}$

Republika menyediakan berbagai rubrik yang mewakili berbagai usia guna memenuhi kebutuhan pembaca. Seperti rubrik Gen: I berisi komuni-

${ }^{15}$ Suf Kasman, Pers dan Pencitraan Umat Islam di Indonesia..., h. 170-175.

${ }^{16}$ Darmanto, "Pemberitaan Media Massa tentang Pengakuan Lembaga Internasional Worldhelp yang Membawa 300 Anak Korban Bencana Alam Tsunami di Aceh (Analisis Framing Harian Republika dan Kompas)", Skripsi (tidak dipublikasikan.), Fakultas Dakwah IAIN Walisongo, 2005, h. 53. 
tas, musik dan film, rubrik Leasure yaitu suplemen Republika tentang tren gaya hidup, tips yang bisa dinikmati segala usia. Terdapat pula rubrik Islam Digest, hadir setiap hari Ahad berisi informasi yang dikemas untuk menambah wawasan dan pengetahuan sejarah peradaban Islam, selain itu terdapat hiburan cerpen dan kisah Muslim. Republika memiliki kolom bercirikan keislaman, yaitu kolom Hikmah berupa kolom tentang persoalan terhangat yang mengaitkannya dengan pelajaran agama, disertai ayat alQur'an dan Hadis. Berita bertema penggunaan jilbab bagi polisi wanita (polwan) muncul secara rutin serta mendapat tanggapan secara serius oleh berbagai kalangan, mulai awal Juni 2013 di Surat Kabar Harian Republika. Pada bulan tersebut terdapat banyak berita mengenai keinginan polwan menggunakan jilbab yang tidak didukung oleh peraturan seragam dinas polwan. Surat Keputusan (SK) Kepala Kepolisian Republik Indonesia (Kapolri) No Pol: Skep/702/IX/2005 tidak menjelaskan adanya seragam jilbab untuk polwan. Jilbab tidak termasuk dalam Standard Operating Procedure (SOP) seragam yang harus dipakai. Polwan, dan terdapat sanksi bila melanggar SK tersebut. ${ }^{17}$

Menggunakan jilbab adalah hak asasi manusia dan salah satu cara melaksanakan perintah Allah utuk menutup aurat, sehingga banyak pihak yang menyayangkan kebijakan tersebut. Berbagai kalangan narasumber berita ikut menaggapi hal tersebut, baik dari institusi kepolisian, lembaga keagamaan, organisasi kemasyarakatan, hingga angota Dewan Perwakilan Rakyat. Permintaan izin polwan berjilbab sudah muncul pertengahan 2012, tetapi baru mendapat respon secara serius setahun kemudian. Terdapat desakan dari berbagai pihak untuk meninjau surat keputusan seragam dinas polwan, tujuannya agar memperbolehkan penggunaan jilbab saat bertugas.

Pada tanggal 20 November 2013, perjuangan polwan dan berbagai pihak agar memperoleh izin berjilbab mendapat titik terang. Kapolri Jenderal Sutarman memberi izin secara lisan penggunaan jilbab bagi polwan, kebijakan tersebut mendapat respon positif dari berbagai kalangan. Perizinan tersebut memiliki persyaratan, yaitu polwan harus membeli jilbab sendiri karena Polri belum menganggarkan penyediaan seragam jilbab. Model dan warna jilbab juga harus sama dengan polwan di Aceh. Polwan

${ }^{17}$ Rosita Budi Suryaningsih, "Polwan Minta Izin Berjilbab", Republika. No. 147 Tahun 21. Edisi 5 Juni 2013. 
Aceh sudah diizinkan berjilbab sejak tahun 2004, sehingga dapat menjadi contoh polwan di luar daerah tersebut. Perasaan gembira polwan tidak bertahan lama, pada tanggal 28 November 2013, terbit telegram rahasia yang ditanda tangani oleh Wakil Kepala Polri Komisaris Jenderal Oegroseno.

Telegram rahasia tersebut berisi penundaan penggunaan jilbab bagi polwan, karena pada pelaksaannya polwan menggunakan jilbab dengan warna dan model tidak seragam. Selain itu belum terdapatnya anggaran pengadaan seragam jilbab bagi polwan menjadi alasan penundaan. Polwan harus menunggu peraturan resmi yang menjamin jilbab dapat digunakan saat bertugas. Kebijakan tersebut terkesan mendadak dan ganjil, karena dalam kurun waktu satu minggu Kapolri mengganti keputusannya, setelah sempat mengijinkan secara lisan. Melalui kronologi tersebut, penulis mengambil sampel masing-masing dua berita untuk dianalisis pada bab selanjutnya. Substansi dibagi menjadi tiga bagian, di antaranya ketika belum mengizinkan, saat mengizinkan, dan menunda penggunaan jilbab bagi polisi wanita.

Tabel 1

Substansi Berita Untuk Dianalisis

\begin{tabular}{|c|l|l|c|c|}
\hline No. & Sunstansi & \multicolumn{1}{|c|}{ Judul Berita } & Edisi & Halaman \\
\hline 1 & \multirow{2}{*}{$\begin{array}{l}\text { Belum } \\
\text { Mengizinkan }\end{array}$} & Polwan Minta Izin Berjilbab & 5 Juni 2013 & 26 \\
\cline { 3 - 5 } & $\begin{array}{l}\text { Pimpinan Polri tak Berhak } \\
\text { Larang Polwan Berjilbab }\end{array}$ & 16 Juni 2013 & 2 \\
\hline 2 & Mengizinkan & $\begin{array}{l}\text { Mulai Hari Ini Polwan Bebas } \\
\text { Kenakan Jilbab }\end{array}$ & 20 Nov. 2013 & 1 \\
\cline { 3 - 5 } & $\begin{array}{l}\text { Kapolri Janji Terbitkan Perkap } \\
\text { Jilbab }\end{array}$ & 21 Nov. 2013 & 1 \\
\hline 3 & \multirow{2}{*}{ Menunda } & Jilbab Polwan Ditunda & 30 Nov. 2013 & 1 \\
\cline { 3 - 5 } & $\begin{array}{l}\text { Kapolri Harus Revisi } \\
\text { Telegram Jilbab }\end{array}$ & 2 Des. 2013 & 2 \\
\hline
\end{tabular}

\section{Belum Mengijinkan Polwan Menggunakan Jilbab Saat Bertugas}

Isi berita mengenai aduan beberapa polisi wanita kepada Majelis Ulama Indonesia (MUI) dan ustadz, tentang keinginannya memakai jilbab 
saat bertugas yang terbentur dengan aturan seragam dinas dari Polri. Terdapat Surat Keputusan (SK) Kepala Kepolisian Republik Indonesia (Kapolri) No Pol: Skep/702/IX/2005, di dalamnya, jilbab tidak termasuk dalam Standard Operating Procedure (SOP), jika tetap memakainya akan mendapat sanksi. Banyak pihak yang menanggapi persoalan tersebut, seperti Wakil Sekretaris Jenderal Majelis Ulama Indonesia (MUI), Tengku Zulkarnaen. Menurutnya alasan pelarangan penggunaan jilbab bagi polwan bertolak belakang dengan Undang- Undang 1945 yang menjamin kebebasan menjalankan ibadah sesuai ajarannya, dan syariat Islam mewajibkan wanita menutup aurat. Pada akhir berita, muncul pendapat anggota Dewan Perwakilan Rakyat dari Partai Keadilan Sejahtera (PKS), Zainuddin, yang berjanji menindaklanjuti keluhan polwan tersebut. Kutipan pendapat narasumber terkait permasalahan tersebut lebih terfokus pada pihak yang menyayangkan peraturan tersebut, di antaranya berasal dari Wakil Sekretaris Jenderal MUI yang permasalah jilbab, Polwan selaku orang yang meminta izin berjilbab, Ustaz sebagai ahli agama, dan anggota DPR dari Partai Keadilan Sejahtera salah satu perwakilan untuk menampung dan menindak lanjuti aspirasi masyarakat.

Berita berjudul "Polwan Minta Izin Berjilbab", merupakan tindak lanjut dari pengaduan salah seorang polwan yang tidak diizinkan berjilbab saat bertugas. Permasalahan tersebut sudah lama muncul, tetapi baru mendapat tanggapan serius oleh berbagai pihak yang memperdulikan. Berbeda halnya dengan polwan di Aceh, yang telah sudah diperbolehkan berjilbab, karena menutup aurat dengan jilbab merupakan peraturan daerah yang wajib dipatuhi seluruh wanita Aceh.

\section{Pengijinan Penggunaan Jilbab bagi Polwan}

Isi berita mengenai sikap MUI yang menegaskan syariat Islam mewajibkan semua wanita Muslim untuk menutup aurat, salah satunya dengan menggunakan jilbab. Melalui Wakil Sekretaris Jenderal MUI Amir Syah, menegaskan kembali bahwa Polri tidak berhak melarang polwan berjilbab atas dasar syariat Islam tersebut. Amir meminta peninjauan kembali surat keputusan Kapolri yang tidak memasukkan jilbab ke dalam seragam dinas polwan. Menurutnya, seragam jilbab yang nantinya dipakai oleh polwan tidak harus terlalu longgar, tetapi tetap menutupi aurat. Perizinan penggunaan jilbab mendapat sambutan positif dari berbagai 
instantsi kepolisian, seperti di Polres Bekasi, sebanyak 91 anggota polwan bersyukur atas kebijakan tersebut. Kabid Humas Polda Jawa Timur Kombes Awi Setiyono juga mendukung penuh jika ada polwan yang ingin mengenakan jilbab, karena berjilbab merupakan hak asasi manusia.

\section{Penundaan Ijin Memakai jilbab}

Penundaan ijin jilbab kembali terjadi pada 30 Nopember 2013. Berita menjadi headline di halaman pertama, dengan sudut pandang sikap tidak konsisten Polri merusak sukacita polwan. Terdapat foto polwan berjilbab untuk mendukung berita. Berita yang dimuat berisi informasi mengenai penggunaan jilbab tampak polwan yang kurang beraturan, sehingga perlu ditunda ijinnya. Banyak polwan menggunakan jilbab dengan warna dan tata cara tidak sesuai polwan di Aceh. Rupa-rupa jilbab tersebut mengurangi konsep kekompakan Polri dalam berbusana, oleh karena itu Polri menerbitkan telegram rahasia agar menunda penggunaan jilbab bagi polwan. Kebjiakan penundaan penggunaan jilbab termuat dalam telegram rahasia (TR) yang ditandatangani Wakil Kepala Polri Komisaris Jenderal Oegroseno, bertanggal Kamis, 28 November 2013. TR berisi enam imbauan kepada polwan untuk menunda penggunaan jilbab saat berdinas hingga terbit peraturan dan perlemen menyepakati anggaran penyediaan jilbab.

\section{Analisis Pemberitaan Media Mengenai ijin jilbab}

Penulis dalam hal ini menggunakan analisis media menurut konsep Van Djik. Van Dijk menggambarkan wacana ke dalam tiga dimensi, yaitu teks, kognisi sosial, dan konteks sosial. Pertama, dimensi teks, van Dijk melihatnya sebagai suatu bangunan yang terdiri atas tiga struktur saling mendukung dan di dalamnya terdapat elemen-elemen lebih kecil. Kedua, dimensi konteks sosial, mempelajari bangunan wacana yang berkembang dalam masyarakat mengenai suatu masalah. Ketiga, dimensi kognisi sosial, mempelajari proses produksi teks berita yang melibatkan kognisi individu wartawan..$^{18}$ Dimensi teks meliputi tematik, skematik, dan semantic. Pada aspek tematik terdapat tiga kategori yaitu belum mengizinkan penggunaan jilbab, mengizinkan penggunaan jilbab, dan menunda penggunaan jilbab bagi polwan. 224.

${ }^{18}$ Eriyanto, Analisis Wacana: Pengantar Analisis Teks Media, (Yogyakarta: LKiS, 2001), h. 
Topik yang ingin disampaikan dalam berita yakni pengaduan seorang polisi wanita (polwan) yang tidak diperbolehkan mengenakan jilbab kepada MUI. Wartawan menggunakan kata perempuan yang mengandung konotasi untuk menunjuk pada polwan. Wartawan menginginkan publik mengetahui bahwa polwan tidak mendapat izin untuk memakai jilbab saat bertugas. Tujuannya agar pihak yang berkompeten seperti MUI, DPR, dan Polri segera menanggapi hal itu. Hal ini penting untuk diperhatikan karena pada kasus pelarangan penggunaan jilbab siswi sekolah negeri pada tahun 1980-an sudah menemukan solusi. Berupa penyempurnaan peraturan seragam sekolah dan memasukkan seragam jilbab dalam SK.100/C/ Kep/D/1991, setelah terjadi pembicaraan intensif antara MUI, Departemen Pendidikan dan Kebudayaan, serta dukungan dari berbagai pihak. ${ }^{19}$ Kasus tersebut menguatkan bahwa jilbab menjadi suatu keharusan yang dijamin dalam surat keputusan dan konstitusi. Republika seolah berharap polwan akan mendapat izin berjilbab jika berbagai pihak membantu memperjuangkan hal tersebut, seperti siswi sekolah negeri saat itu.

\section{Aspek Skematik}

Skematik merupakan strategi wartawan untuk mendukung topik yang ingin disampaikan, dengan memberi penekanan bagian yang didahulukan lalu mana untuk selanjutnya. Republika mengawali berita berjudul "Polwan Minta Izin Berjilbab", dengan mengatakan MUI mendapatkan pengaduan dari polwan yang tidak diperbolehkan mengenakan jilbab. Selanjutnya, Republika menuliskan pendapat Wakil Sekretaris Jenderal MUI Tengku Zulkarnaen, bahwa alasan melarang polwan memakai jilbab bertolak belakang dengan Undang-undang Dasar (UUD) 1945. Pada pertengahan berita, Zulkarnaen terkesan mengancam, jika kepolisian tidak megeluarkan peraturan perizinan polwan berjilbab, maka jalan yang ditempuh yaitu datang ke Mahkamah Konstitusi (MK) untuk membatalkan pelarangan. Dilanjutkan pendapat polwan Kepolisian Daerah Jawa Tengah (Polda Jateng) yang mengadu kepada Ustaz Wahfiudin tentang keinginannya berjilbab saat berdinas. Ustaz Wahfiudin juga terlihat mendukung keinginan polwan. Selanjutnya, wartawan menjelaskan, polwan Jateng pernah

\footnotetext{
${ }^{19} \mathrm{M}$. Syamsudini, "Kasus Jilbab di Sekolah-sekolah Negeri di Indonesia". dalam laman blog http://mydetik.blogspot.com/2011/06/kasus-jilbab-di-sekolahsekolah-negeri.html. diakses 9 Juni 2013.
} 
menulis surat permintaan izin berjilbab, namun tidak dikabulkan, bahkan keluar. Peraturan yang menegaskan polwan berjilbab hanya diperbolehkan di Polda Aceh. Pada akhir berita, wartawan menuliskan pendapat anggota DPR dari Partai Keadilan Sejahtera (PKS) Zainuddin, yang berjanji menindaklanjuti keinginan polwan mengenakan jilbab.

Republika mengawali berita dengan menuliskan hal-hal yang dilanggar Polri jika melarang penggunaan jilbab bagi polwan, baru dilanjutkan kronologi dan pendapat polwan yang menginginkan berjilbab. Susunan tersebut terkesan mebangun citra negatif kepolisian sebagai instansi penegak hukum, yakni jika tidak mengizinkan polwan berjilbab, maka Polri akan melanggar UUD 1945. Dipertegas dengan pemilihan narasumber kontra terhadap tidak diizinkannya polwan berjilbab. Seperti pemilihan pendapat MUI, diletakkan pada awal berita dan diberi porsi banyak, sehingga mengesankan tidak perlu ada pelarangan karena lembaga pemberi fatwa permasalahan keagamaan sudah menegaskan Polri akan melanggar hak menjalankan ibadah.

\section{Aspek Semantik}

Semantik mempelajari makna apa yang ditekankan dalam teks, terdapat beberapa elemen elemen yang diamati, yaitu latar, detil, maksud, dan pra anggapan. Latar dapat menjadi alasan pembenaran gagasan yang diajukan suatu teks, dipakai untuk menyediakan latar belakang akan dibawa kemana makna teks tersebut. Kata sudah pernah, pada awal kalimat menjadi titik berat yang ingin disampaikan wartawan. Dilanjutkan penggunaan koherensi atau kepaduan makna, pada kata tetapi, yang menyatakan pertentangan. Berfungsi menambah kejelasan suatu pemaparan, yaitu surat permohonan izin berjilbab tidak dikabulkan Kapolri. Wartawan juga member penekanan menggunakan kata hubung bahkan. Bermaksud menunjukkan akibat dari permohonan izin berjilbab yaitu keluar surat edaran Kapolri yang menegaskan seragam jilbab Polri hanya untuk polwan di Polda Aceh. Alasan tersebut menjadi latar belakang polwan Jateng mengadu mengenai tidak diizinkannya berjilbab. Republika ingin mengatakan bahwa sejumlah polwan sudah berusaha meminta izin berjilbab pada Kapolri, akan tetapi hasilnya tidak sesuai harapan. Akan lebih efektif jika masyarakat dari berbagai kalangan ikut bertindak dan mendukung perizinan pemakaian jilbab bagi polwan. 


\section{Aspek Detail}

Elemen wacana detil berhubungan dengan kontrol informasi yang ditampilkan wartawan dalam berita, diuraikan secara panjang atau tidak Penggunaan kata jaminan dalam kutipan tersebut menunjukkan telah ada lindungan hak menjalankan ibadah dalam UUD 1945, dasar dari semua undang-undang. Kata syariat dan dasar hukum jilbab terkesan dipengaruhi ideologi keislaman Republika. Republika menampilkan pendapat secara detail, dimulai dari pasal dan isi undang-undang yang menjamin kebebasan menjalankan ibadah, hingga hukum jilbab dalam Islam bagi wanita. Strategi tersebut membangun wacana bahwa sebagai lembaga penegak hukum, Polri telah mengabaikan jaminan hak dalam UUD 1945, bahkan melanggar konstitusi apabila tidak mengizinkan polwan berjilbab.

\section{Aspek Maksud}

Elemen maksud menunjukkan bagaimana secara implisit dan eksplisit wartawan menggunakan praktik bahasa tertentu untuk menonjolkan kebenaran dan menyembunyikan kebenaran tersebut Republika menjelaskan secara implisit mengenai jumlah polwan yang ingin berjilbab, hanya menuliskan cukup banyak. Selanjutnya, secara eksplisit menuliskan alasan terhalangnya keinginan polwan menggunakan jilbab saat berdinas karena belum ada peraturan Kapolri tentang penggunaan seragam jilbab polwan di luar Polda Aceh. Penulisan tersebut terkesan memberi maksud tidak sedikit polwan yang ingin berjilbab, namun terhalang dengan belum adanya peraturan seragam jilbab di luar polda Aceh. Paragraf tersebut memperlihatkan ekspresi kecewa Republika terhadap Polri, dan terkesan menunggu langkah Polri mengeluarkan peraturan seragam jilbab polwan.

\section{Aspek Pra Anggapan}

Elemen wacana pra anggapan merupakan upaya mendukung pendapat dengan memberikan premis yang dapat dipercaya kebenarannya. Republika menggunakan kata seandainya untuk memandang peristiwa yang mungkin terjadi. Penempatan kata seandainya, pada awal kalimat terkesan menghakimi jika pengandaian terjadi. Aspek sintaksis. Sintaksis mempelajari bagaimana pendapat narasumber ditampilkan dalam berita. Elemen yang diamati sintaksis, meliputi kata ganti, koherensi, dan bentuk kalimat. Elemen kata ganti digunakan untuk menunjukkan di mana posisi seseorang 
dalam wacana atau berita. Kata ganti kami menunjukkan orang pertama jamak yang menyatakan kelompok di luar pembaca, sehingga menumbuhkan jarak antara pembaca dan narasumber berita. Kata ganti kami dalam berita tersebut, mewakili Zainuddin dan anggota DPR dari Partai Keadilan Sejahtera (PKS), partai politik berbasis Islam. Pemilihan tersebut tentunya mengandung maksud, Republika memandang DPR sebagai dewan yang berwenang membuat undang-undang. Setidaknnya, menyampaikan permasalahan mengenai tidak diizinkannya polwan berjilbab kepadanya, akan membawa perubahan, ditambah dengan PKS sebagai partai Islam, tentu aspirasi polwan akan mendapat respon serius.

\section{Aspek Koherensi}

Koherensi merupakan pertalian antarkata, proposisi atau kalimat, yang ditampilkan dalam bentuk sebab akibat, bisa juga sebagai penjelas. Republika menggunakan koherensi pertentangan dengan kata penanda tetapi, untuk memperjelas pemaparan. Kalimat kedua menduduki posisi lebih penting daripada yang pertama Terdapat penekanan yang ingin diperlihatkan Republika, yaitu Kapolri tidak mengabulkan keinginan polwan Polda Jateng untuk berjilbab. Kalimat tersebut menggambarkan usaha polwan yang belum mendapatkan hasil. Republika terkesan ingin menunjukkan usaha tersebut kepada publik, dan mengharapkan dukungan agar polwan mendapat izin berjilbab. Bentuk kalimat menentukan apakah subjek diekspersikan secara eksplisit atau implisit dalam teks berita. Republika menggunakan kalimat aktif untuk menuliskan isi berita. Kalimat aktif memberi penekanan pada siapa yang melakukan. Pada kalimat tersebut, wartawan menggunakan kata mengadu, dengan menjelaskan secara eksplisit bahwa polwan menyampaikan keinginannya mengenakan jilbab kepada ustaz. Subjek dalam kalimat tersebut adalah polwan yang mengadukan keinginannya berjilbab. Stilistik mempelajari pilihan kata apa yang dipakai dalam teks. Elemen yang diamati adalah leksikon, mengenai pemilihan kata atas berbagai kemungkinan kata yang tersedia. Wartawan Republika memilih kata "melarang" untuk menuliskan pendapat Zulkarnaen. Kata lain yang memiliki makna hampir sama dengan melarang, yaitu menghalangi, membatasi, tidak memperbolehkan. Kata melarang, menggambarkan terdapat pihak yang tidak memperbolehkan penggunaan jilbab bagi polwan, dalam hal ini pihak yang dimaksud adalah Polri. Polri terkesan mengabaikan hak 
menjalankan ibadah sesuai agama, yang dilindungi dalam UUD 1945, dengan tidak memperbolehkan polwan berjilbab saat bertugas.

\section{Aspek Retoris}

Retoris berhubungan mengenai bagaimana dan dengan cara apa penekanan dilakukan dalam teks. Elemen yang diamati, yaitu grafis, metafora, dan ekspresi. Republika menaruh perhatian besar pada berita berjudul "Polwan Minta Izin Berjilbab", dengan menonjolkan kutipan wawancara dari anggota DPR fraksi Partai Keadilan Sejahtera (PKS) Zainuddin. Kutipan tersebut ditulis dalam bentuk capture dengan warna latar hitam, tulisan putih, dan berbentuk lingkaran sehingga terlihat menonjol. Warna hitam menyimbolkan kekuasaan, putih melambangkan harapan, sedangkan lingkaran menggambarkan kesatuan utuh. Maksud dari gambar tersebut, yaitu Republika, polwan, dan narasumber berharap agar DPR serta Kapolri, selaku pihak yang berkuasa, segera menangani permasalahan penggunaan jilbab polwan.

Metafora digunakan sebagai ornamen dari buku, bisa disampaikan lewat kiasan, ungkapan sehari-hari, pepatah, sebagai alasan pembenar atas pendapat tertentu kepada publik Makna yang dimaksud dalam kalimat yakni rasa ingin melawan atau memberontak terhadap peraturan Polri yang tidak memperbolehkan polwan berjilbab. Polwan tersebut ingin mengenakan jilbab semenjak pulang menunaikan ibadah haji, untuk melengkapi ketaatan terhadap perintah agama Islam. Elemen ekspresi bertujuan memeriksa apa yang ditekankan oleh seseorang dalam teks. Ekspresi kekecewaan ditunjukan dalam berita penyesalan Zulkarnaen terhadap kebijakan seragam jilbab polwan, dengan mengatakan, "Jika alasannya kebijakan otonomi khusus, mengapa kebijakan ini tidak bisa diperlebar pada tingkat nasional?" Zulkarnaen menunjukkan kekurangpuasan terhadap kebijakan perizinan berjilbab hanya diterapkan di Polda Aceh, bukan di seluruh Indonesia. Republika memandang permasalahan tersebut sebagai persoalan Nasional, karena masyarakat Indonesia mayoritas Muslim, sehingga pemakaian jilbab harus diizinkan.

\section{Kesimpulan}

Republika terlihat mengharapkan polwan dapat bebas berjilbab saat bertugas tanpa perlu mengkhawatirkan adanya teguran. Terlihat dari pemilihan narasumber berita yang kebanyakan memiliki harapan sama 
dengan Republika. Kutipan wawancara narasumber yang menginginkan polwan berjilbab diberi porsi lebih banyak dan ada yang diletakkan pada awal serta akhir berita. Wartawan menyusun serta memilih kutipan pendapat narasumber berdasarkan kerangka acuan yang telah dibuat, dengan memperhatikan aspek penting tidaknya pendapat tersebut ditempatkan di bagian atas, tengah, atau akhir berita.]

\section{Daftar Pustaka}

Darmanto, "Pemberitaan Media Massa tentang Pengakuan Lembaga Internasional Worldhelp yang Membawa 300 Anak Korban Bencana Alam Tsunami di Aceh (Analisis Framing Harian Republika dan Kompas)". Skripsi tidak dipublikasikan, Fakultas Dakwah IAIN Walisongo, 2005.

Eriyanto, Analisis Wacana: Pengantar Analisis Teks Media. Yogyakarta: LKiS, 2001.

Fahmiarto, Anjar. Staf redaksi/editor berita Republika. Pada 3 Juli 2014.

Hanafi, Muchlis Muhammad, dkk., Kedudukan dan Peran Perempuan (Tafsir alQur'an Tematik). Jakarta: Lajnah Pentashihan Mushaf al-Qur'an Badan Litbang dan Diklat Departemen Agama RI, 2009.

Ibrahim, Abdul Mu'min, Mendidik Anak Perempuan. (terj) Abdul Hayyie al-Kattani dan Mujiburrahman Subadi. Jakarta: GemaInsani Press, 2007.

Kasman, Suf, Pers dan Pencitraan Umat Islam di Indonesia (Analisis Isi Pemberitaan Harian Kompas dan Republika). Jakarta: Balai Litbang dan Diklat Kementrian Agama RI, 2010.

Mustafa, Kholid, Manajemen Wanita Salehah, Yogyakarta: Diva Press, 2004.

Nurudin, Jumalisme Masa Kini. Jakarta: Rajawali Pers, 2009.

Prambadi, Gilang Akbar dan Alicia Saqina. "Jilbab tak Ganggu Polwan". Republika. No. 149 Tahun 21. Edisi 8 Juni 2013.

Prambadi, Gilang Akbar. "Jilbab Polwan Ditunda". Republika. No. 248 Tahun 21. Edisi 30 November 2013.

Prambadi, Gilang Akbar. "Mulai Hari Ini Polwan Bebas Kenakan Jilbab". Republika. No. 238 Tahun 21. Edisi 20 November 2013.

Priboemi. "Jilbab Sudah Ada Ribuan Tahun". http://zangpriboemi.blogspot. com/2012/09/mendalami-sejarah-jilbab.html. Diakses 17 Juli 2013. 
Republika Online. "About ROL (Republika Online)". Web. Lihat dalam: http://www.Republika.co.id/page/about\#. Diakses 9 Desember 2013.

Sabiq, Zamzami. "Kognisi Sosial (Social Cognition)". Blog. Lihat dalam: http://zamzamisabiq.blogspot.com/2012/09/kognisi-sosial-socialcognition.html. Diakses 17 Maret 2013.

Samantho, Ahmad Y., Jumalistik Islami; Panduan Praktis bagi Para Aktivis Muslim. Jakarta: Harakah, 2002.

Shihab, M. Quraish, Jilbab Pakaian Wanita Muslimah. Jakarta: Lentera Hati, 2005.

Syamsudini, M. "Kasus Jilbab di Sekolah-sekolah Negeri di Indonesia". Lihat dalam: http://mydetik.blogspot.com/2011/06/kasus-jilbab-di- sekolahsekolah-negeri.html. Diakses 9 Juni 2013.

Syuqqah, Abdul Halim Abu, Kebebasan Wanita. (terj) As'ad Yasin. Jakarta: Gema Insani Press, 1997.

Suryaningsih, Rosita Budi. "Polwan Minta Izin Berjilbab". Republika. No. 147 Tahun 21. Edisi 5 Juni 2013.

Wikipedia. "Republika (Surat Kabar)". dalam: http://id.wikipedia.org/wiki/ Republika_(surat_kabar). Diakses 9 Desember 2013.

Zamzani, Fitriyan. "Momen Polri Merengkuh Kemanusiaan". Republika. No. 155 Tahun 21. Edisi 14 Juni 2013. 